\title{
The Effect of Cervicogenic Headache on the Myoelectrical Activities of Suboccipital Muscles, Range of Motion and Functional Activities of the Neck at Different Ages
}

\author{
MOHAMED A. EMAM, M.Sc.*; FATMA S. AMIN, Ph.D.*; DOAA I. AMIN, Ph.D.* and RADWA AZMY, M.D.** \\ The Departments of Basic Sciences, Faculty of Physical Therapy* and Neurology, Faculty of Medicine**, Cairo University
}

\begin{abstract}
Background: Cervicogenic Headache (CGH) represents a major health problem, aggravating Quality of Life (QOL) and work productivity. The Suboccipital Muscles (SOM) have been identified as playing a role in cervical pain, and are therefore a target for rehabilitation.

Aim of the Study: To asses the effect of CGH on myoelectrical activities of suboccipital muscles, functional activities and ROM of neck.

Subjects and Methods: Thirty patients with CGH of both genders participated in this study. They were recruited from the out patient clinic of Kasr El-Ainy and thirty normal subjects, their ages ranged from 18-55 years old. They were randomly assigned into 2 experimental groups: Group A (1835 years)-group B (36-55 years) \& 2 control groups: Group C (18-35 years)-group D (36-55 years). Myoelectrical activities was measured by Natus nicolet vikingquest to analyze the motor unit potentials by quantitative measures \& neck range of motion was measured by Cervical Range of Motion (CROM) device and functional activities of the neck was measured by Neck Disability Index (NDI).

Results: There was non significance increase in myoelectrical activities of the suboccipital muscles in cervicogenic patients than normal subjects with $(p$-value $=0.147)$. And there was statistical significant decrease in all ROM values and functional activities in cervicogenic patients than normal subjects in cervicogenic patients than normal subjects with $(p$-value $<0.05)$.
\end{abstract}

Conclusion: This study provides sound evidence for SOM alterations in in myoelectrical activities in patients with $\mathrm{CGH}$.

Key Words: Cervicogenic headache - The suboccipital muscles - Electromyography - Neck disability index.

\section{Introduction}

CERVICOGENIC Headache (CGH) is a subgroup of secondary headaches may be associated

Correspondence to: Dr. Mohamed A. Emam, The Department of Basic Science, Faculty of Physical Therapy, Cairo University with increasing age [1]. It may be arising from musculoskeletal dysfunction of the cervical spine, especially the upper three cervical segments or coming about because of a serious underlying disease such as a brain tumor, aneurysm, infection, or inflammatory disease and but may present as referred pain from other regional structures, for example, the teeth, nose, ears, or neck [2]. Headache is a common condition influencing $47 \%$ of the global population with Cervicogenic Headache (CGH) representing $15-20 \%$ of all chronic and recurrent headaches. CGH affect $2.2-2.5 \%$ of the adult population and seem to affect women four times more than men [3]. Functional impairments (diminished strength and endurance) in the cervical muscles and poorer muscle control of the deep cervical flexors have been shown in patients with cervicogenic headache [4]. The International Headache Society (IHS) described the pain as being uni lateral or bilateral, influencing the head or face but has most commonly affected the occipital region, frontal region, or retro-orbital region. Also it is characterized by unilateral headache with signs and symptoms of neck involvement, such as, pain by movement, by external pressure over the upper cervical, and/or sustained awkward head positions [5]. The Suboccipital Muscles (SOM) are a group of four muscles located posteriorly at the highest point of the cervical spine between the occiput, $\mathrm{C} 1$ and $\mathrm{C} 2$. They have been identified as playing a role in cervical pain, and are therefore a target for rehabilitation and intervention in some cervical spine disorders. Clinically they are of interest as they have been identified as undergoing changed motor activity after whiplash are said to develop myofascial trigger points and contribute to cervicogenic headache and chronic tension type headache together the muscles are named: Rectus capitis 
posterior major, rectus capitis posterior minor, obliquus capitis superior and obliquus capitis inferior [6].

Electromyography (EMG) is an electrodiagnostic medicine technique utilized for evaluating and recording the electrical activity produced by skeletal muscles. EMG is performed using an instrument called an electromyograph to produce a record called an electromyogram. An electromyograph recognizes the electric potential generated by muscle cells when these cells are electrically or neurologically activated. The signals can be analyzed to detect medical abnormalities, activation level, or recruitment order, or to analyze the biomechanics of human or animal movement [7].

Previous studies showed the magnitude, size of suboccipital muscles and macroscopic content of fat in the cervical muscles using conventional MRI and Ultrasonography [8]. Previous studies showed also that RCPmi hypertrophy could contribute to the pathogenesis of chronic headache by impacting the so-called 'myodural bridge', a connection between the rectus capitis posterior minor (RCPmi) and the spinal dura [9]. Therefore the purpose of this study is to asses the effect of cervicogenic headache on myoelectrical activities of suboccipital muscles, functional activities and ROM of neck at different ages.

\section{Subjects and Methods}

Subjects: Asample of thirty cervicogenic headache patients and thirty normal subjects of both gender participated in this study after approval of the Research Ethical Committee (No: P.T.REC/012/ 001847) of Faculty of Physical Therapy, Cairo University. All participants signed a written informed consent before the procedures. The patients were recruited from the out patient clinic of Kasr Al-Ainy and external clinic of Faculty of Physical Therapy, Cairo University from Feb. 2018-Oct. 2018 diagnosed, and referred from a neurologist. The diagnosis was confirmed by IHS classification of CGH and Cranio cervical flexion rotation test. Normal subjects were recruited using posters, social media and by verbal invitations. They were assigned into 4 groups according to age 2 experimental groups: Group A (18-35 years)-group B (36-55 years) and 2 control groups: Group C (18-35 years)group D (36-55 years).

The participants were included if the following criterias are present according to IHS (Headache Classification Committee of the International Head- ache, 2013): Unilateral pain starting in the neck and radiating to the frontotemporal region, pain aggravated by neck movement, restricted Cervical Range of Motion (CROM), joint tenderness in at least one of the joints of the upper cervical spine (C1 -C3) and headache frequency of at least 1 per month over the past year. Participants had to be between 18 and 55 years both male and female patients [10].

The participants were excluded if they had previous history of injury or surgery of head and neck, musculoskeletal problems/disorders (e.g. cervical radiculopathy, myopathy, advanced osteoporosis, head/neck trauma), neurological problems /diseases (e.g. Parkinson's disease, stroke) and metabolic syndromes (e.g. diabetes, hypo/ hyperthyroidism).

\section{Instrumentation: Evaluative procedures:}

At the beginning, the demographic data of the participants was recorded (name, age, weight, height, Body Mass Index (BMI), telephone number and medical history. The following parameters was measured as follow:

\section{1- Cranio cervical flexion-rotation test:}

The Cervical Flexion-Rotation Test (CFRT), is an easily applied clinical test purportedly biased to assess dysfunction at the $\mathrm{C} 1-\mathrm{C} 2$ motion segment. The C1-C2 motion segment represents for $50 \%$ of the rotation in the cervical spine [11]. In this test procedure, the cervical was fully flexed, trying to isolate movement to $\mathrm{C} 1-\mathrm{C} 2$, which has an unique ability to rotate in flexion. Normal range of rotation motion in end range flexion has been shown to be $44^{\circ}$ to each side. Conversely, subjects suffering from headache with $\mathrm{C} 1-\mathrm{C} 2$ dysfunction have an average of $17^{\circ}$ less rotation [12]

\section{Technique:}

1- Patient was relaxed in supine.

2- Examiner fully flexed the cervical spine with the occiput resting against the examiners abdomen.

3- The patient's head was then rotated to the left and the right.

4- If a firm resistance was encountered, pain provoked, and range was limited before the expected end range, then the test was rated positive, with a presumptive diagnosis of limited rotation of C1 on C2 [13] Fig. (1). 

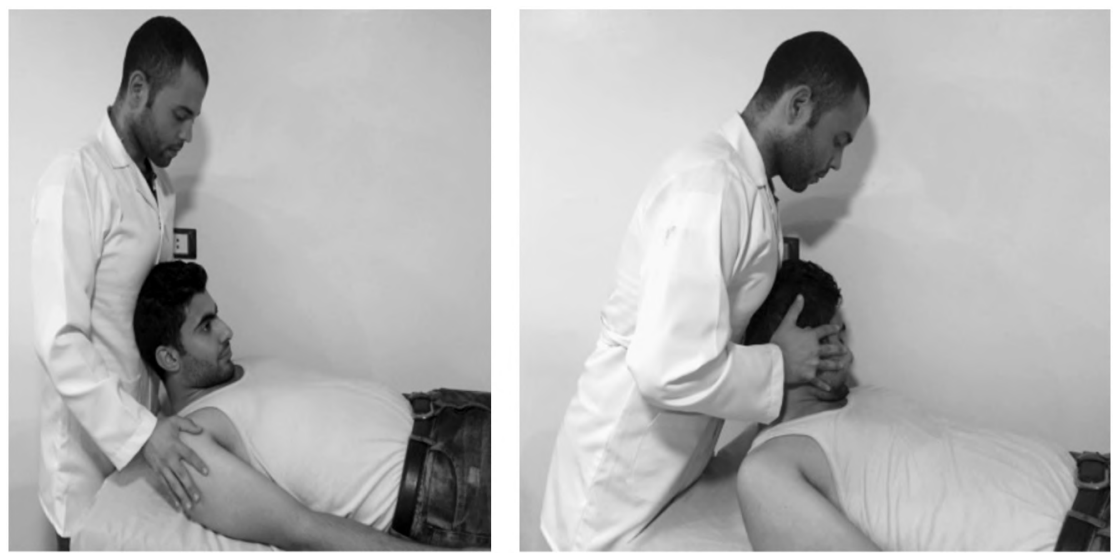

Fig. (1): Cranio cervical flexion-rotation test.

\section{2- Functional neck disability:}

It was measured by the NDI which is a 10 -item questionnaire consist of pain intensity, personal care, lifting, reading, headache, concentration, work, driving, sleeping and recreation. The subject was instructed to circle one of the six options which describes the severity of each item (0-5) that most closely suited their condition at the present time [14].

Then the marks was counted and divided by 50 or 45 if one section was missing with total score ranging from 0 (no pain ordisability) to 50 (severe pain and disability [15]. Then was multiplied by 100 for the percentage (score/50) X 100=---\% points [16]. A score of $10-28 \%$ is mild disability, $30-48 \%$ is moderate, $50-68 \%$ is sever and $72 \%$ or more is complete [17]

\section{3- Quantative EMG of suboccipital muscles activ- ities (mainly rectus capitis post. muscles):}

Electromyography (EMG) is an electrodiagnostic medicine technique utilized for evaluating and recording the electrical activity produced by skeletal muscles. An electromyograph recognizes the electric potential generated by muscle cells when these cells are electrically or neurologically activated. Needle electromyography is a definitive invasive technique that allows an objective evaluation of muscle activity. The use of EMG has played a major role in the understanding of muscle activity during $\mathrm{CGH}$ the signals can be analyzed to detect medical abnormalities, activation level, or recruitment order, or to analyze the biomechanics of human or animal movement [7].
Activation pattern of the examined muscle was recorded and analyzed using EMG as follow:

A- Skin preparation [18]: After history taking and physical examination, subjects was allowed to rest for 10 minutes for acclimatization. Pending this period each subject was prepared for the experimental set as follow:

- The skin was cleaned with alcohol with a piece of cotton to reduce skin impedance at the sites of recorded muscle and of the reference electrode.

Needle electrodes positions [19]:

The electrodes sites was located on each subject's symptomatic side as following protocol: Concentric needle was inserted in the rectus capitis post. muscles. A similar procedure was Continued for needle insertion into the targeted muscle [11]

\section{Rectus Capitis Posterior Muscles (RCPm):}

The needle was inserted, with the bevel positioned caudad, at a point $1-2 \mathrm{~cm}$ lateral to the midline at the level of the approximation of the posterior arch of $\mathrm{C} 1$. The needle was directed cephalad and angled approximately 80 degrees from an imaginary line drawn parallel to the surface of the skin in the midsagital plane. The needle was inserted until bone (occiput) was reached and withdrawn slightly. Then the patient performed extension delivering maximum voluntary contraction against therapist hand.

Reference electrode: Just above the middle of the spine of the right scapula or over the forehead. Fig. (2) Electrodes placement sites was determined utilizing a marker and a tape measurement and confirmed during palpation and manual resistance. 

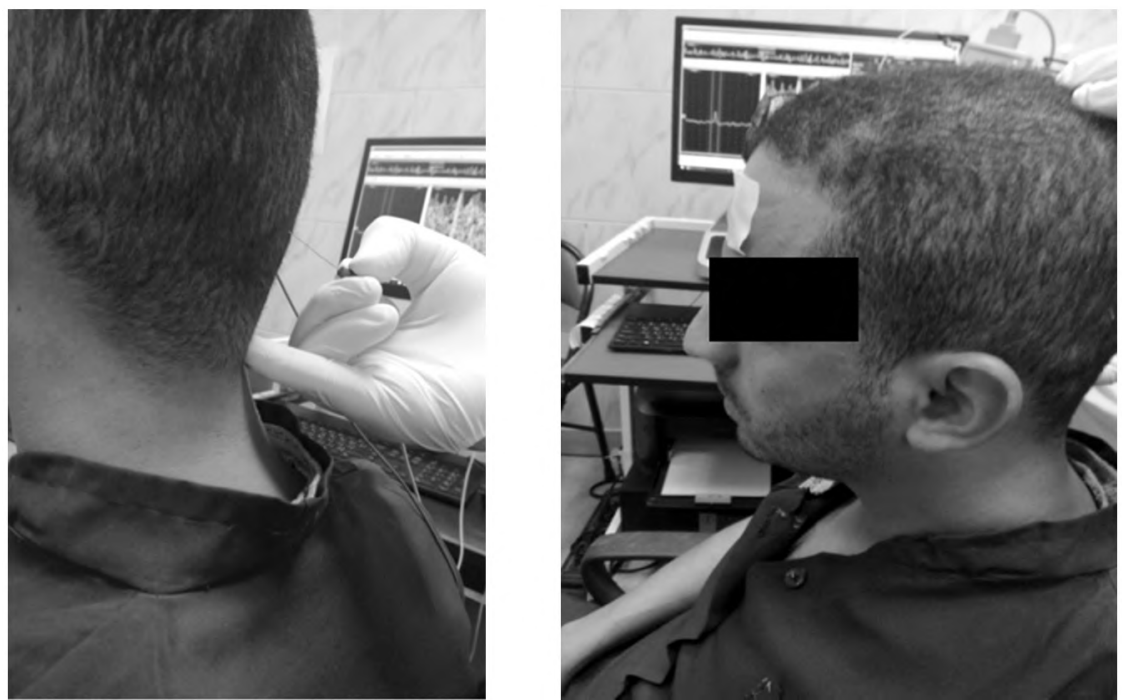

Fig. (2): Needle insertion ground electrode over forehead.

\section{4- Cervical Range of Motion (CROM):}

The CROM measures the cervical range of motion for flexion, extension, lateral flexion and rotation using separate inclinometers. Measurements were expressed in degrees with high degree of validity [20] and reliability [21].

Cervical AROM in flexion and extension, right/ left lateral flexion, and right/left rotation was measured for each subject Fig. (3).

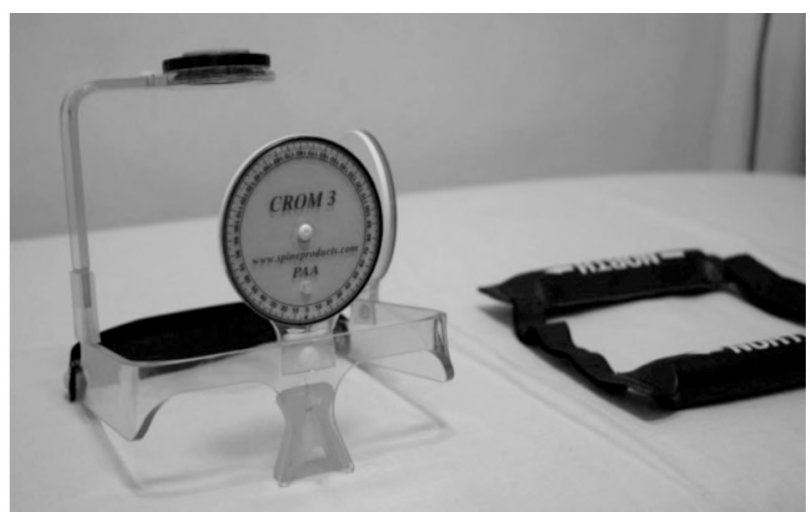

Fig. (3): Cervical range of motion device.

All participants were instructed to sit in a straight-backed chair with feet rested flat on the floor and upper extremities positioned at the sides with shoulder relaxed.

The CROM was strapped to participant head and then they were asked to place their head in neutral position to be 0 . Two Magnet bar were placed on the neck anteriorly and posteriorly by soft belt for adjustment of compass of CROM.

Every subject then performed 2 repetitions of each motion through a comfortable yet complete AROM to ensure subject familiarity.
Two sets of 6 measurements were performed. For each set, the six cervical motions were measured once, with no rest time between each cervical motion. A 30-second rest occurred between sets 1 and 2, pending which the CROM was removed from the subject and then reapplied. The order and direction (right-left)of the measurements was randomized at the start of each set by having the subject pick cards, on which were listed all possible orders of planes and directions of movement to be measured [22].

\section{Flexion and extension:}

Specific instructions given to the subject for performance of flexion were, "tuck your chin first, then move your head forward and down as far as possible until limited by tightness or discomfort". No manual stabilization was given pending these movements, just verbal cueing. Fig. (4).

\section{Right and left side bending:}

Specific instructions for performance of lateral flexion in each direction were, "stare straight ahead and side-bend your neck by moving your ear toward your shoulder as far as possible until limited by tightness or discomfort". To avoid thoracic and shoulder girdle movement, the subject was also instructed,"do not move your shoulders or change the amount of pressure being applied to the backrest of your chair." Fig. (5).

\section{Right and left rotation:}

The tester was standing directly behind and above the subject, such that the top of the subject's head and the tip of the subject's nose were visible to the tester. Specific instructions for performance of rotation in each direction were, "turn your head, gazing at an imaginary horizontal line on the wall, 
as far as possible until limited by tightness or discomfort”. Fig. (6).

\section{Data analysis:}

The outcomes measured were suboccipital myoelctrical activities by Natus nicolet vikingquest to analyze the motor unit potentials by quantitativemeasures \& neck range of motion was measured by Cervical Range of motion(CROM) device. Functional activities of the neck was measured by Neck Disability Index (NDI).

Statistical analysis was conducted using SPSS for windows, Version 25 (SPSS, Inc., Chicago, IL). Prior to final analysis, data were screened for normality assumption and presence of extreme scores. This exploration was done as a pre-requisite for parametric calculations of the analysis of difference. Descriptive analysis using histograms with the normal distribution curve and Normality test of data using Shapiro-Wilk test showed that the data of age, height, weight, BMI, MUP Amplitude (right), MUP Amplitude (left), and NDI in all groups were normally distributed and not violates the parametric assumption. Other dependent variables were not normally distributed at least in one of the study groups. Independent sample $t$-test was used for comparison between normally distributed variable among each age-related group while MannWhitney Test was used for comparison between non normally distributed variables among each age related groups. Alpha level was 0.05 .

\section{Sample size:}

Sample size was calculated according to pilot study on 12 subjects, equally distributed on two groups $\mathrm{CGH}$ and non $\mathrm{CGH}$, considering EMG amp. primary outcome, with mean \pm SD (641.47 \pm 260.06$)$ and $(436.41 \pm 151.02)$ respectively. Calculation using $\mathrm{G}^{*}$ power ver. 3.1.9 free software (university of dusseld of Germany)showed that effect size between subjects was (0.96) with $80 \%$ power (1-Beta), probability 0.05 and alpha level of 0.5 give us optimal sample size of (29) for each group.
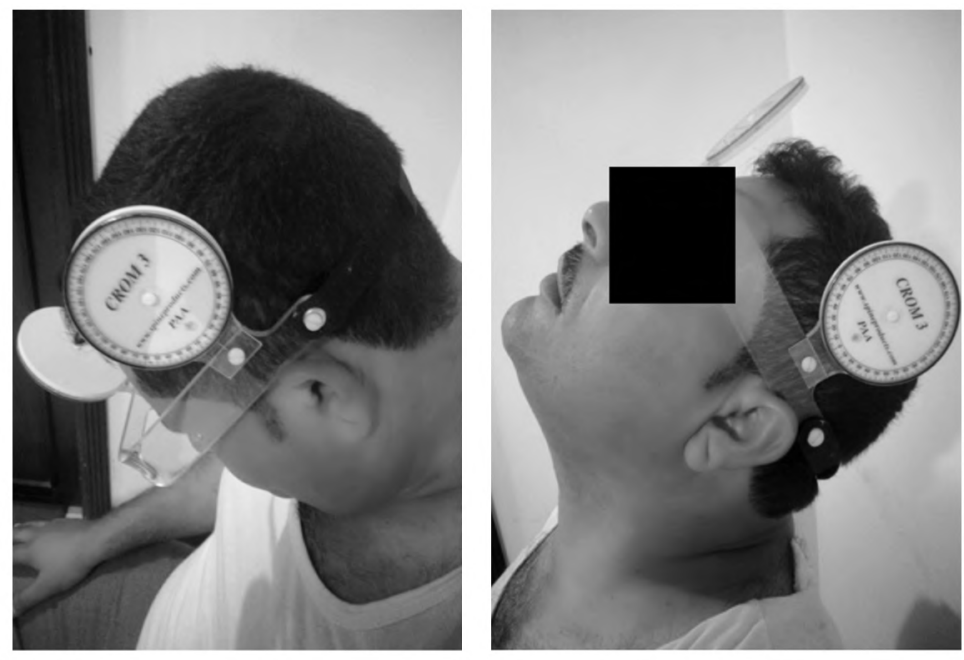

Fig. (4): Flexion and extension.
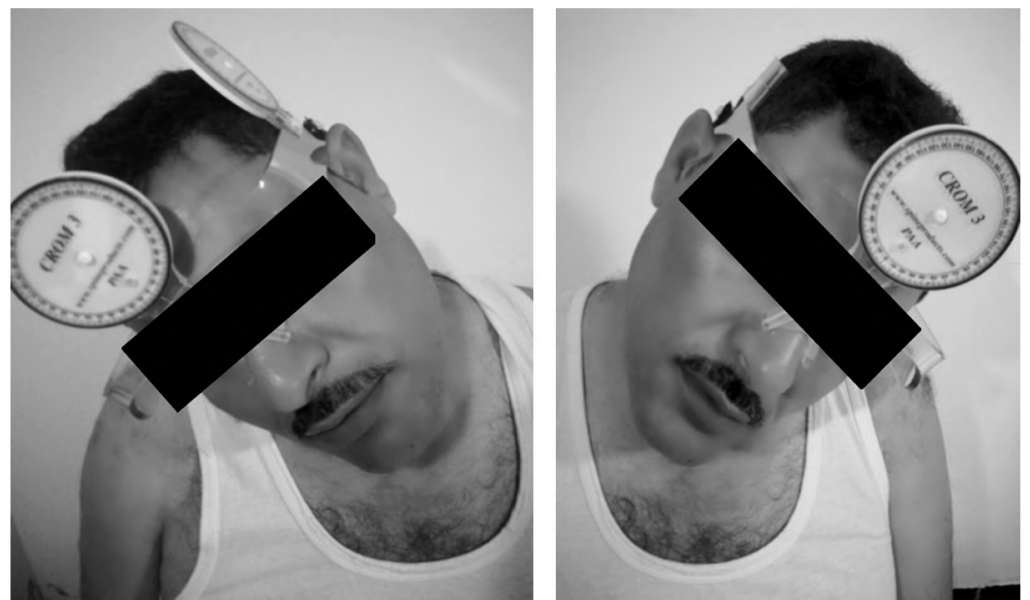

Fig. (5): Right and left sidebending. 

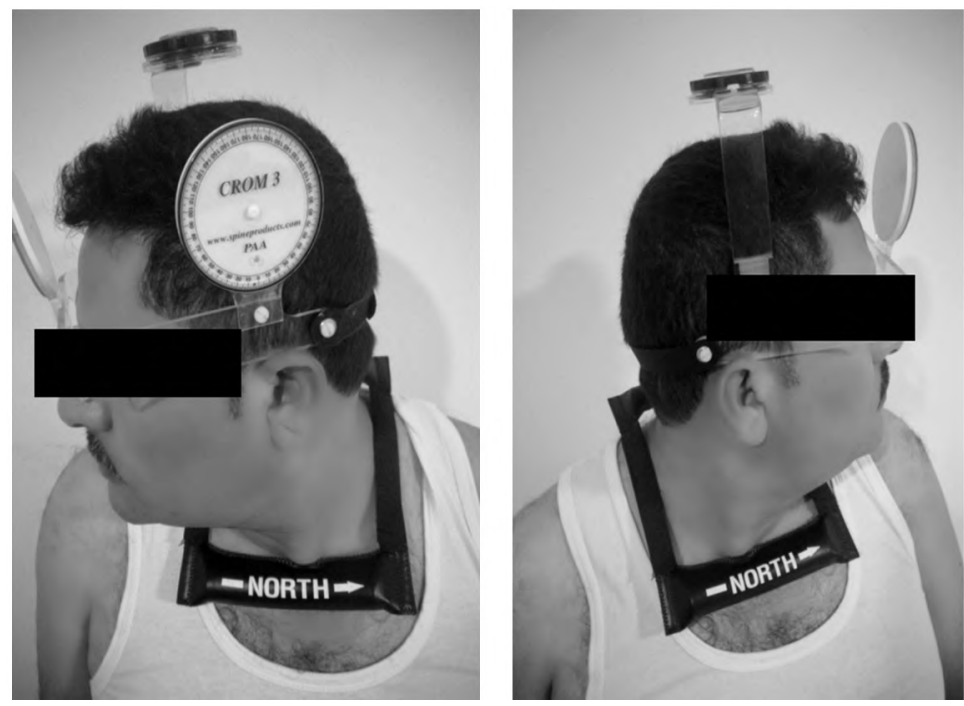

Fig. (6): Right and left rotation.

\section{Results}

Demographic and clinical characteristics of participants:

The baseline characteristics of the participants showed that no statistically significant differences existed between the groups as regards mean age, weight, height and body mass index $(p>0.05)$ as shown in (Table 1).
Comparison between Motor Unit Potentials amplitude (MUAP) on 4 groups.

There was significant increase of myoelectrical activities of suboccipital muscles in the affected side (right) of patients with CGH group (A\&B) than non affected side in the same patients and than right side of the muscles in normal subject group (C \& D) without stastical difference between them $(p$-value $=0.332)$. As shown (Table 2$)$.

Table (1): The age and the body dimensions (mean \pm STD) with normality test (in parentheses) of the experimental and the control patients.

\begin{tabular}{|c|c|c|c|c|c|c|}
\hline & $\begin{array}{c}\text { Group (A) } \\
\text { Mean } \pm \text { S.D. }\end{array}$ & $\begin{array}{c}\text { Group (B) } \\
\text { Mean } \pm \text { S.D. }\end{array}$ & $\begin{array}{c}\text { Group (C) } \\
\text { Mean } \pm \text { S.D. }\end{array}$ & $\begin{array}{c}\text { Group (B) } \\
\text { Mean } \pm \text { S.D. }\end{array}$ & $\begin{array}{c}p \text {-value } \\
\text { A \& C }\end{array}$ & $\begin{array}{c}p \text {-value } \\
\mathrm{B} \& \mathrm{D}\end{array}$ \\
\hline Age (years) & $28.333 \pm 5.024$ & $47.667 \pm 6.298$ & $27.667 \pm 5.728$ & $47.200 \pm 4.523$ & 0.737 & 0.817 \\
\hline Height (c.m) & $157.933 \pm 5.750$ & $160.333 \pm 8.006$ & $158.800 \pm 6.700$ & $162.533 \pm 7.425$ & 0.707 & 0.442 \\
\hline Weight (k.g) & $74.467 \pm 12.563$ & $81.867 \pm 9.884$ & $72.600 \pm 12.631$ & $80.800 \pm 11.085$ & 0.688 & 0.783 \\
\hline BMI & $29.918 \pm 5.025$ & $31.906 \pm 3.907$ & $28.820 \pm 4.912$ & $30.495 \pm 2.880$ & 0.550 & 0.270 \\
\hline Level of significance & Non significant & & & & & \\
\hline
\end{tabular}

Table (2): Comparison between four groups in MUAP.

\begin{tabular}{|c|c|c|c|c|c|c|}
\hline & \multicolumn{2}{|c|}{ Group (A) } & \multirow{2}{*}{$\frac{\text { Group (C) }}{\text { RT side }}$} & \multicolumn{2}{|c|}{ Group (B) } & \multirow{2}{*}{$\frac{\text { Group (D) }}{\text { RT side }}$} \\
\hline & $\begin{array}{l}\text { Affected side } \\
\text { (RT) }\end{array}$ & $\begin{array}{l}\text { Non affected } \\
\text { Side (left) }\end{array}$ & & $\begin{array}{l}\text { Affected side } \\
\text { (RT) }\end{array}$ & $\begin{array}{c}\text { Non affected } \\
\text { Side (left) }\end{array}$ & \\
\hline Mean & 511.667 & 593.467 & 422.067 & 665.267 & 625.067 & 495.667 \\
\hline$\pm \mathrm{SD}$ & 315.230 & 351.667 & 155.807 & 347.088 & 330.536 & 109.043 \\
\hline$p$-value & 0.332 & 0.163 & 0.332 & 0.082 & 0.133 & 0.082 \\
\hline Level of significance & \multicolumn{2}{|c|}{ Non significant } & \multicolumn{3}{|c|}{ Non significant } & \\
\hline
\end{tabular}


Comparison between four groups in CROM measurements:

Mann-Whitney tests revealed there was Significant decreas in mean values of flexion, Rt \& Lt sidebending and $\mathrm{Rt} \& \mathrm{Lt}$ rotation CROME in patients with CGH group (A \& B) than normal subject group $(\mathrm{C} \& \mathrm{D})(p<0.05)$.

Mann-Whitney tests revealed there was decrease in mean values of extension CROME between both groups (group a and group C) without stastical difference $(p$-value $=0.116)$. While there was significant decrease in median values of extension CROME between both groups (group $\mathrm{b}$ and group $\mathrm{D})$ with $(p$-value $<0.001)$ as shown in (Table 3$)$.

Comparison between four groups in Neck Disability Index (NDI):

Also, there was Significant decrease in mean values of NDI in patients with CGH group (A \& B) than normal subject group $(\mathrm{C} \& \mathrm{D})$ with $(p$ value $<0.001$ ). As shown in (Table 4).

Table (3): Comparison between four groups in CROM measurements.

\begin{tabular}{lccccc}
\hline & $\begin{array}{c}\text { Group (A) } \\
\text { Median } \\
p \text {-value }\end{array}$ & $\begin{array}{c}\text { Group (C) } \\
\text { Median } \\
p \text {-value }\end{array}$ & $\begin{array}{c}\text { Group (B) } \\
\text { Median } \\
p \text {-value }\end{array}$ & $\begin{array}{c}\text { Group (D) } \\
\text { Median } \\
p \text {-value }\end{array}$ & $\begin{array}{c}\text { Level } \\
\text { of } \\
\text { significance }\end{array}$ \\
\hline Flexion & 10.200 & 20.800 & 11.630 & 19.370 & Significant \\
Extension & 0.001 & 0.001 & 0.015 & 0.015 & \\
& 13.030 & 17.970 & 9.900 & 21.100 & Non significant \\
Rt sidebending & 0.116 & 0.116 & 0.000 & 0.000 & \\
& 10.370 & 20.630 & 9.600 & 21.400 & Significant \\
Lt sidebending & 0.001 & 0.001 & 0.000 & 0.000 & Significant \\
& 9.300 & 21.700 & 9.800 & 21.200 & \\
Rt rotation & 0.000 & 0.000 & 0.000 & 0.000 & Significant \\
& 8.670 & 22.330 & 8.670 & 22.330 & Significant \\
Lt rotation & 0.000 & 0.000 & 0.000 & 0.000 & 22.530 \\
\end{tabular}

Table (4): Comparison between four groups in Neck Disability Index (NDI)

\begin{tabular}{llclc}
\hline & $\begin{array}{c}\text { Group } \\
(\mathrm{A})\end{array}$ & $\begin{array}{c}\text { Group } \\
(\mathrm{C})\end{array}$ & $\begin{array}{c}\text { Group } \\
(\mathrm{B})\end{array}$ & $\begin{array}{c}\text { Group } \\
\text { (D) }\end{array}$ \\
\hline Mean & 37.067 & 9.933 & 38.267 & 10.800 \\
$\pm \mathrm{SD}$ & 3.535 & 7.343 & 3.411 & 7.646 \\
$p$-value & 0.000 & & 0.000 & \\
Level of significance & Significant & \multicolumn{2}{l}{ Significant } \\
\hline
\end{tabular}

\section{Discussion}

The primary objectives of the current study was to asses the effect of cervicogenic headache on myoelectrical activities of suboccipital muscles, functional activities and ROM of neck at different ages.

Cervicogenic headache is a classification of headache in which pain is referred from the cervical spine. This category of headache is typically chronic, presented as unilateral cephalgia, and is believed to be caused by musculoskeletal dysfunction of the neck [23].
Previous researches showed the magnitude and size of suboccipital muscles and macroscopic content of fat in cervical muscles by MRI and ultra sonography but uptill now there were limited studies about the CGH and Myoelectrical activities of suboccipital muscles, ROM and functional activities of the neck.

The results of current study concluded that there was significant increase in myoelectrical activities in cervicogenic subjects than normal subjects but without statistical difference and there was statistical significant decrease in ROM values of flexion, right $\&$ left side bending and right $\&$ left rotation in $G(A)$ \& $G(B)$ than $G(C) \& G(D)$ and there was decrease in extension ROM in $G$ (A) \& G (B) than $G$ (C) \& G (D) but with nonstatistical significant difference and comparison between NDI showed that there was decrease in qulity of life in $G$ (A) \& $G(B)$ than $G(C) \& G$ (D).

The results of current study concluded that negative correlation between right side bending, left side bending and age in $G$ (A) while weak negative correlation between right side bending and age in $G(B)$. 
The results of the current study can be explained by the following Group $(A) \&(B)$ :

\section{1- EMG activities (MUP):}

There was increase in myoelectrical activities in cervicogenic subjects than normal subjects but without statistical difference, this increase is may be due to the central effects of the headache syndrome itself are in charge of hyperactivity of the neck muscles: Especially RCPmi that may constitute a general phenomenon in specific headache types. Headache patients have generally shown higher EMG activity in the neck muscles. Increased muscle activity will lead to muscle hypertrophy [24].

This hypertrophy may be due to an association between the RCPmi and the spinal dura via the Myodural Bridge (MDB) can influence headaches by either increasing the tension on the cranial dura or interfering with the cerebrospinal fluid circulation through the subarachnoid space, muscle hypertrophy due to excessive muscle tension may be a contributing element to the chronification of symptoms [25].

The results of the current study are inagreement with [26] who showed. That the RCPmi is activated through ventral translation of the head ongoing activity during positions that include ventral translation of the head (e.g. during computer work) could therefore result in hypertrophy of the RCPmi. Previous publications demonstrated a correlation between ventral translation of the head and chronic headaches supporting this hypothesis [27].

The results of the current study agree with [28] who investigated the Magnetic Resonance Imaging (MRI) images of the rectus capitis posterior minor muscle (RCPmi) of 115 chronic headache patients (diagnosis not further specified) and of both genderfree participants, for changes in cross-sectional size and found that male participants in both groups showed larger RCPmi and, more to the point, that the RCPmi in the headache group was significantly larger than in the non-headache group.

The results of the current study reject with [29] who found that RCPmi hypertrophy is a protective mechanism for a sensitized nervous system, including the spinal dura mater. Central sensitization has been shown in two-thirds of the migraine population and in Tension Type Headache (TTH) and is an explanation for a range of clinical phenomena including scalp tenderness and tender points.

In conclusion, the current study provides sound evidence for suboccipital muscle alterations in patients with CGH but it cannot provide evidence for a contribution of the neck to chronic headache symptoms and there is no stastitcal difference related to small size of the sample and not chronification of the symptoms.

\section{2- $R O M$ :}

There was decrease in ROM in headache subjects than normal subjects. The results of the current study agree with, who have reported significant decreases in active ROM in those with CGH. The reduced cervical ROM is likely to be secondary to the pericranial muscle tenderness, although pain eli-cited from other structures in the neck might alsoplay a role [30]

The results of the current study reject with (Hall T, Robinson K. (2004) who have found no significant differences in AROM when contrasted with asymptomatic subjects [31]. These findings also suggest that subclassifying CGHs into traumatic versus atraumatic origin may be of value, since headache and neck ROM are inversely related in patients who have sustained a whiplash injury [32]

The results of the current study reject with. (Hall Tb and Robinson K 2014) who found that active range of motion assessment in CGH patients and asymptomatic subjects to be identical.

Ogince et al., compared CGH patients with subjects having migraine with aura and asymptomatic subjects. Again no difference could be found and hence one cannot distinguish between a patient with migraine and $\mathrm{CGH}$ by assessing the active ROM. This could be because of the fact that adjacent segments are able to compensate for the loss of movement at a hypomobile segment.

\section{3- NDI:}

Quality of life was impaired in CGH patients implying limited activities of daily living, more reliance on medicinal substances and medical aids, not enough energy and mobility, more pain and discomfort, insufficient sleep and rest and poor work capacity [10]

The results of the current study agree with [33] who found that the severity of this disorder leads to excess of 18 million annual office visits in the United States.

The results of the current study agree with [34] who conducted study of 37 patients with cervicogenic headache and 292 control group, it was discovered that mean scores of quality of life in the CGH group were significantly worse in all of eight SF-36 domains than those of the control 
group, indicating that the degree of disability in $\mathrm{CGH}$ is substantial.

\section{Conclusion:}

The current study provides sound evidence for suboccipital muscle alterations in patients with $\mathrm{CGH}$ but it cannot provide evidence for a contribution of the neck to chronic headache symptoms.

\section{References}

1- UTHAIKHUP S., ASSAPUN J., KOTHAN S., WATCHARASAKSILP K. and ELLIOTT J.M.: "Structural changes of the cervical muscles in elder women with cervicogenic headache". Musculoskeletal. Sci. Pract., 29: 1-6, 2017.

2- RUBIO-OCHOA J., BENITEZ-MARTINEZ J., LLUCH E., SANTACRUZ-ZARAGOZA S., GOMEZ-CONTRERAS P. and COOK C.E.: "Physical examination tests for screening and diagnosis of cervicogenic headache: Asystematic review”. Man. Ther., 21: 35-40, 2016.

3- RACICKI S., GERWIN S. and DiCLAUDIO S.: "Conservative physical therapy management for the treatment of cervicogenic headache: A systematic review" J. of Manual and Manipulative Therapy, 21 (2): 113-24, 2013.

4- DUMAS J.P., ARSENAULT A.B., BOUDREAU G., MAGNOUX E., LEPAGE Y. and BELLAVANCE A.: "Physical impairments in cervicogenic headache: Traumatic vs. nontraumatic onset”. Cephalalgia, 21: 884-93, 2001.

5- SEDIGHI A., NAKHOSTIN ANSARI N. and NAGHDI S.: "Comparison of acute effects of superficial and deep dry needling into trigger points of suboccipital and upper trapezius muscles in patients with cervicogenic headache". Journal of Bodywork and Movement Therapies, 2017.

6- JON C., SCOTT F. and PHILIP W.: "Fibre types of human suboccipital muscles”. Eur. J. Anat., 20 (1): 31-6, 2016.

7- KAMEN and GARY: "Electromyographic Kinesiology. In Robertson, DGE et al., Research Methods in Biomechanics. Champaign, IL: Human Kinetics Publ, 2004.

8- JULL G. and STANTON W.: "Predictors of responsiveness to physiotherapy management of cervicogenic headache". Cephalalgia, 25: 101-8, 2005.

9- KAHKESHANI K. and WARD P.J.: "Connection between the spinal dura mater and suboccipital musculature: Evidence for the myodural bridgeand a route for its dissection a review". Clin. Anat., 25: 415-2, 2012.

10- KOCJAN and JANUSZ: "Quality of life of patients with cervicogenic headaches". Journal of Education, Health and Sport, 2016.

11- HALLGREN R.C., ANDARY M.T., WYMAN A.J. and ROWAN J.J.: "A standardized protocol for needle placement in suboccipital muscles". Clin. Anat., 21 (6): 5018, 2008.

12- OGINCE M., HALL T., ROBINSON K. and BLACKMORE A.M.: "The diagnostic validity of the cervical flexion-rotation test in C1/2-related cervicogenic headache". Man. Ther. [Internet], 12 (3): 256-62, 2007.
13- Physiopedia contributors: "Cervical Flexion-Rotation Test”. (December 5). Physiopedia, . Retrieved from https:// . www. physiopedia. com/index . php?title=Cervical_ Flexion-Rotation_Testandoldid=181005, 2017.

14- CHAN M., CLAIR D. and EDMONDSTON S.: "Validity of the Neck Disability Index and Neck Pain and Disability Scale for Measuring Disability Associated with Chronic, Non-Traumatic Neck Pain". Man. Thera., 14: 433-8, 2009.

15- GAY R., MADSON T. and CIESLAK K.: "Comparison of the Neck Disability Index and the Neck Bournemouth Questionnaire in Sample of Patients with Chronic Uncomplicated Neck Pain". J. Manipulative Physio. Ther., 25962, 2007.

16- VERNON H. and MIOR S.: "The Neck Disability Index: A Study of Reliability and Validity". J. Manipulative Physiol. Ther., 14 (7): 409-15, 1991.

17- DAWOOD R., NASEF S., KATTABEI O., et al.: "Effectiveness of Kinesio Taping versus Cervical Traction on Mechanical Neck Dysfunction": M.Sc. Thesis. Faculty of Physical Therapy. Cairo University, 20-30, 2012.

18-McLEAN L.: "The Effect of Postural Correction on Muscle Activation Amplitudes Recorded from The Cervicobrachial Region". J. Electromyogr. Kinesiol., 15: 527-35, 2005.

19- ALI O., NASEF S. and REZK-ALLAH S.: "Cervical and Thoracic Extensor Muscles Activation Pattern in Low Back Pain". Faculty of Physical Therapy Cairo University: MSC thesis, 12-16, 2012.

20- FLETCHER J.P. and BANDY W.D.: " Intrarater reliability of CROM measurement of cervical spine active range of motion in persons with and without neck pain". J. Orthop. Sports Phys. Ther., 38 (10): 640-5, 2008.

21- TOUSIGNANT M., De BELLEFEUILLE L., O'DONOUGHUE S. and GRAHOVAC S.: Criterion validity of the cervical range of motion (CROM) goniometer for cervical flexion and extension. Spine, 25 (3): 324-30, 2000.

22- De KONING C.H., VAN DEN HEUVEL S.P., STAAL J.B., SMITS-ENGELSMAN B.C. and HENDRIKS E.J.: Clinimetric evaluation of active range of motion measures in patients with non-specific neck pain: A systematic review. European Spine Journal, 17 (7): 905-21, 2008.

23- HOWARD P.D., BEHRNS W., MARTINO M.D., DIMAMBRO A., MCINTYRE K. and SHURER C.: "Manual examination in the diagnosis of cervicogenic headache: A systematic literature review". J. Man. Manip. Ther., 23 (4): 210-8, 2015.

24- OKSANEN A., PÖYHÖNEN T. and YLINEN J.J.: "Force produc-tion and EMG activity of neck muscles in adolescent headache". Disabil Rehabil, 30: 231-9, 2008.

25- KAHKESHANI K. and WARD P.J.: "Connection between the spinal dura mater and suboccipital musculature: Evidence for the myodural bridge and a route for its dissection-A review”. Clin. Anat., 25: 415-22, 2012.

26- McPARTLAND J.M. and BRODEUR R.R.: "Rectus capitis posterior minor: A small but important suboccipital muscle”. J. Bodyw. Mov. Ther., 3: 30-5, 1999.

27- FERNÁNDEZ-DE-LAS-PENÃS C., ALONSO-BLANCO C., CUADRADO M.L., et al.: "Forward head posture and neck mobility in chronic tension-type headache: A blinded, controlled study". Cephalalgia, 26: 314-9, 2006. 
28- YUAN X.Y., YU S.B., LIU C., et al.: "Correlation between chronic headaches and the rectus capitis posterior minor muscle: A comparative analysis of cross-sectional trail". Cephalalgia. Epub ahead of print 17 August, 2016.

29- GOADSBY P.J.: "Migraine, Allodynia, Sensitisation and All of That."Eur. Neurol., 53 (Suppl 1): 10-6, 2005.

30- KNACKSTEDT H., et al.: "Cervicogenic headache in the general population: The Akershus study of chronic headache." Cephalalgia, 30 (12): 1468-76, 2010.

31- HALL T. and ROBINSON K.: "The flexion-rotation test and active cervical mobility: A comparative measurement study in cervicogenic headache”. Manual Therapy, 9: 197-202, 2004.
32- KASCH H., et al.: "Headache, neck pain, and neck mobility after acute Whiplash injury: A prospective study". Spine (Phila Pa 1976), 26 (11): p. 1246-51, 2001.

33- BOLINE P.D., KASSAK K., BRONFORT G., NELSON C. and ANDERSON A.V.: "Spinal manipulation vs. amitriptyline for the treatment of chronic tension-type headaches: A randomized clinical trial. J. Manipulative Physiol. Ther., 18: 148-54, 1995.

34- VAN SUIJLEKOM H.A., LAME I., STOMP-VAN DEN BERG S.G., KESSELS A.G. and WEBER W.E.: "Quality of life of patients with cervicogenic headache: A comparison with control subjects and patients with migraine or tension-type headache". Headache, 43: 1034-41, 2003.

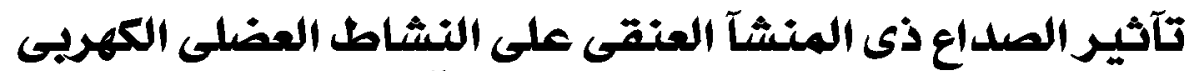

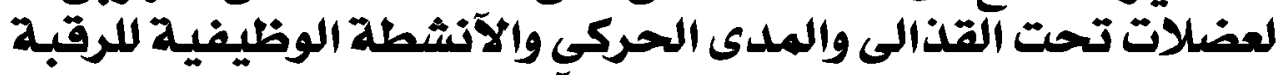 فى مختلف الآعمار
}

\author{
يهدف هذا البحث إلى ثآثير المداع ذيى المنثـاً العنقى على النشاط العضلى الكهربى لعضلات تحت القذالى والمدى الحركى والآنشطة \\ الوظيفية للرقبة في مختلف الآعمار.

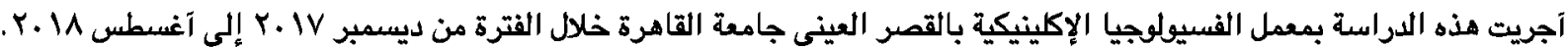 \\ تم إجراء هذا البحث على ثلاثين ثخص لديهم صداع ذيى منثاً عنقى وثلاثين شخص آصحاء من مرضى بالعيادة الخارجية بالقصر العينى

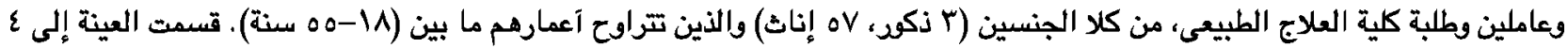

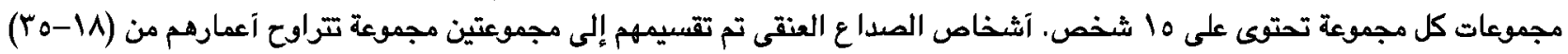

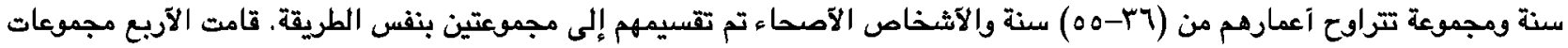

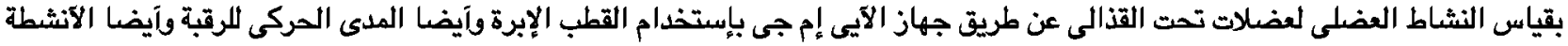

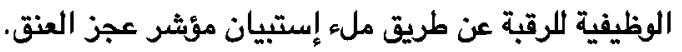 \\ يوجل زيادة في النشاط العضلى الكهربائى لدى الآثخاص المصابين بالصداع ذى المنشا العنقى آكثر من الآثخاص الآصحاء ولكنها \\ زيادة عميلة وليست ذات دلالة إحصائية. \\ توجد فرقق ذات دلالة إحصائية فى الآنشطة الوظيفية للرقبة عند الآثخاص المصابين بالصداع ذى المنشاً العنقى عن الآثخاص الآصحاء. \\ الإستتاج: يحدث تغيرات فى عضلات تحت القذالى حيث يزيد النشاط العضلى عند الآثخاص الذين يعانو من الصداع ذىى المنشاً العنقى. \\ المدى الحركى للرقبة يقل ف جميع الإتجاهـات ما عدا فرد الرقبة للخلف والنشاط الوظيفى يقل آيضا عند الآثخاص اللذين يعانو من الصداع \\ ذى المنشا العنقى.
}

